\title{
Culture and communication - The interplay in the new public commons: Usenet and community networks
}

\author{
Michael Hauben \\ PO Box 250101, New York, NY 10025-1531, USA \\ Phone: +1212787 9361, Fax: +12126626442 \\ Email: hauben@columbia.edu
}

'Any document that attempts to cover an emerging culture is doomed to be incomplete. Even more so if the culture has no overt identity (at least none outside virtual space). But the other side of that coin presents us with the opportunity to document the ebb and flow, the moments of growth and defeat, the development of this young culture.'

(John Frost, Cyberpoet's Guide to Virtual Culture, 1993)

\begin{abstract}
As we approach the new millennium, social relationships are changing radically. In 1969, the anthropologist Margaret Mead spoke of an 'approaching world-wide culture'. While Mead wrote of a global culture made possible by the electronic and transportation advances of her day, her words actually foresaw fundamental changes that have been substantially enhanced by the computer communication networks that were just beginning in 1969. A new culture is being formed out of a universal desire for communication. This culture is being formed and formulated both by new technology and by social desires. People are dissatisfied with their conditions, whether traditional or modern. Much of the new communication technology facilitates new global connections. This paper will explore the effect of new communication forms on human culture and of human culture on these new communication forms.
\end{abstract}




\section{THE EMERGING GLOBALIZATION OF THE EVERYDAY}

The extensive development of transportation and communication technologies in the twentieth century has linked the world together in ways which make it relatively simple to travel or to communicate with peoples and cultures around the world. The daily exposure of the world's peoples to various cultures makes it impossible for almost any individual to envision the world consisting of only his or her own culture (Mead, 1978). We really are moving into a new global age which affects most aspects of human life. For example, world trade has become extensive, many words are similar across languages, and sports and entertainment are viewed simultaneously by global audiences. The exposure to media and forms of communication helps spread many of these cultural elements. While television and radio connect people with the rest of the world in a rather impersonal and often passive fashion, computer networks are increasingly bringing people of various cultures together in a much more intimate and grassroots manner.

Culture is a difficult concept to define. For example, Tim North has gathered seven different definitions (North, 1994, chapter 4.2.1). One common category in some of these definitions is the passing of previously learned behaviour from one generation to the next. Another common category in the definition of culture is the importance of experience and patterns of behaviour shared among a group of people. Historically, culture has changed slowly and has been passed on from generation to generation. In the last half of the twentieth century, however, for most peoples the rate of cultural evolution has been accelerating. Mead (1978) writes that while, in the past, culture was transmitted from the older generation to the younger with slow change from generation to generation, today the younger generation learns from both its elders and from its peers. The learning from peers is then shared with the elders. Human culture is set by how people live their lives (Graham, 1995). Culture is created and reinforced through how a person lives in the context of society and of social movements. The individual is taught the culture of his or her society while growing up, but those perceptions change as he or she matures, develops, and lives an adult life. Culture is not statically defined. Rather, a person grows up into a culture and then changes it as that life progresses through time (Mead, 1956).

As people increasingly live a more global lifestyle, whether mediated through media, travel or actual experience, culture is changing. This global experience is facilitated by the ability of the individual to interact with people from other cultures and countries on a personal level. Images and thoughts available via mass media show these cultures exist but, when people get a chance to talk and interact, differences become less of an oddity and more of an opportunity (Uncapher, 1992).

There are those who claim this global culture or mass culture is snuffing out individual differences to make a pre-packaged culture. These critics call for the isolation of communities from each other so that their uniqueness can be preserved. This criticism misses the point that human culture is a dynamic element of society, and freezing it would produce a museum of human society. Uncapher (1992) correctly points out that what these critics do not recognize is that, more and more, the people of various cultures are understanding the power of the new communication technologies. More and more people are reacting against the mass media and corporate dominance and calling for a chance to express their views and 
contribute their culture to the global culture. Margaret Mead tells a story (1978, pp. 5-6) of returning to a village in New Guinea which originally requested medicine and trade goods. On this later visit, rather than asking for more contributions of western civilization, the villagers requested their songs be recorded via tape recorder in order to contribute their own culture to the outside world. The presence of radios made the villagers aware of the music of others, and they wanted a part of their culture broadcast around the world.

\section{GLOBAL CONTACT OVER COMPUTER NETWORKS}

The new media of Usenet news, electronic mail and the Internet facilitate the growth of global interactive communities. These forums are made available through community networks, universities, the workplace, Internet access providers, and other public access locations (Hauben and Hauben, 1997). Human culture is ever evolving and developing, and the new public commons are of a global nature. A growing number of people are coming together online and living more of their daily lives with people from around the world. Through the sharing of these moments by people, their cultures are coming to encompass more of the world not before immediately available.

Usenet newsgroups are a relatively young medium of human discourse and communication [1]. In a recent study of the global online culture, Tim North (1994, chapter 5.2) asks the question, 'Is there an on-line culture and society on Usenet?' His conclusion is that there is a definite Usenet culture. He lists four of the important defining aspects of this culture:

1. The conventions of the culture are freely discussed;

2. The culture is not closed to outsiders and welcomes new members;

3. There is a strong sense of community within the net culture;

4. It is what you say, not who you are, that matters.

North proposes, however, that Usenet cannot be considered as a separate society. Rather Usenet is 'a superstructural society that spans many mainstream societies and is dependent upon them for its continued existence' (North, chapter 4.2.2, p. 4).

North argues that the net does not need to provide the physical needs made possible by a society. He writes: 'In this superstructural view, the Net is freed of the responsibilities of providing certain of the features provided by other societies (e.g. reproduction, food and shelter) by virtue of the fact that its members are also members of traditional mainstream societies that do supply them' (North, chapter 4.2.2, p. 4).

Rather, those who use the net live in their offline society and come to the net for other than physical purposes. Others are studying the online culture and the connection to the growing global culture (Avis, 1995; Graham, 1995; Jones, 1991).

Usenet technology was developed by graduate students in the late 1970s as a way to promote the sharing of information and to spread communication between university campuses. This design highlights the importance of the contribution by individuals to the community. Thus the content of Usenet is produced by elements of the community for the whole of the community. In the forming of this public 
space or commons, people are encouraged to share their views, thoughts, and questions with others (Hauben and Hauben, 1997). Usenet provides the chance to contribute to discussions and to interact with other people; it has become a truly global community of people hooking their computers together to communicate. People desire to talk and to communicate with other people (Graham, 1995; Woodbury, 1994).

Both the technological design of opening a computer up to accept the contributions of others and the desire to communicate led to the creation of an egalitarian culture (Jones, 1991; North, 1994; Woodbury, 1994). People have both a chance to introduce and to share their own culture and a chance to broaden themselves through exposures to various cultures. As such, the Usenet culture is an example of a global culture which is not a reflection of purely one culture. Instead, Usenet incorporates cultural elements from many nations and builds a new online culture (North, 1994).

\section{COMMUNITY NETWORKS MAKING ONLINE ACCESS AVAILABLE}

Community networks provide a way for citizens of a locality to hook into these global communities for little or no cost (Graham, 1995). Community networks also provide a way for communities to represent themselves to others connected online (Graham, 1995; Weston, 1994). Without access made available through community networks, through publicly available computer terminals or local dialin phone numbers, only those who could afford the monthly charges or who have access through work or school would represent themselves (Avis, 1995). Particular portraits of various cultures would thus be only partially represented. Also, when access is available and open to all, a greater wealth of contributions can be made.

There is a strong push in Canada and Canadian communities to get online. A lot of grassroots community network building is taking place. A Canadian national organization, Telecommunities Canada, stresses the importance of contributing Canada's various cultures to the online community and, in this way, of making a contribution to the whole community (Graham, 1995; Weston, 1994). In a similar way, Izumi Aizu (1995, p. 6) says that Japan has 'an opportunity to bring its own cultural value to the open world' and, he continues, '(i)t also opens the possibility of changing Japan into a less rigid, more decentralized society, following the network paradigm exercised by the distributed nature of the Internet itself.'

There is something to be said about the attraction of representing one's self to the greater community. The many-to-many form of communication where an individual can broadcast to the community and get responses back from other individuals is an empowering experience. No longer do you have to be rich and powerful to communicate broadly to others and to represent yourself and your own views. This power is making it possible for individuals to communicate with others with similar interests (and different interests) around the world. Grassroots organization is boosted and even the formation of local community groups is accelerated. Development of the commons to the exclusion of the big media representations makes this a grassroots medium or a new enlarged public commons (Felsenstein, 1993). 
The online culture is primarily a written one, although much of the text is generally written in an informal, almost off-the-cuff fashion. While people will post papers and well thought-out ideas, much of the conversation is generated in an immediate response to others' messages. This text can feel like a conversation or a written version of oral culture. Stories akin to the great stories of pre-history come about. Legends and urban myths circulate and are disseminated (Jones, 1991). Pictures and other non-text items can be sent in Usenet messages but these nontext items are primarily transferred and not modified, thought about, or communally worked on as are the textual ideas. The common, shared, online language is English (Aizu, 1995). However, other languages exist in country hierarchies, in newsgroups, and in mailing lists, along with Internet Relay Chat (IRC) channels, gopher sites, and world wide web (WWW) pages.

Text also means that body language and other non-verbal clues need to be spelled out. Extra-sensory emoticons [2] have been invented (for example, <grin>, $<$ laugh $>$, and so on) along with smileys. Smileys are textual drawings of a person's face with a smile or grin rotated 90 degrees counter-clockwise so as to be typeable and printable on computer text screens and printouts [3].

\section{CONCLUSION}

North writes how there is a distinct Usenet culture, and that this culture is open and welcoming to newcomers (1994). He also notes there can be unfriendliness to 'newbies' but he focuses on how the online culture is documented and available for people to learn from documents available online [4]. This description of culture and netiquette (the online word for net etiquette) is available to learn from and open to discussion. Bruce Jones (1991) sums up the net culture:

'...the usenet network of computers and users constitutes a community and a culture, bounded by its own set of norms and conventions, marked by its own linguistic jargon and sense of humor and accumulating its own folklore' (p. 2). Both North (1994) and Jones (1991) elaborate on what they see as an egalitarian tendency or tendency to contribute to the community's benefit. Jones writes:

'...the people of the net owe something to each other. While not bound by formal, written agreements, people nevertheless are required by convention to observe certain amenities because they serve the greater common interest of the net. These aspects of voluntary association are the elements of culture and community that bind the people of usenet together' (p. 4).

The global culture is formed in several ways, none of which is a generic, corporate, rubber stamp. People are taking charge. They are bringing their own cultures into the global culture and spreading this new culture around the world. This is taking on a general form and an online form. The online form provides a strong means by which people can spread their ideas and culture which in turn affects the broader global culture. This broader global culture also affects newsgroups or online media. The ability to express oneself to the rest of the world is addictive and the rapid increase of new people joining the online global community makes that manifest. 'The voice-less and the oppressed in every part of 
the world have begun to demand more power ... The secure belief that those who knew had authority over those who did not has been shaken' (Mead, 1978, p.5).

\section{NOTES}

[1] Usenet was initiated in 1979.

[2] Emoticons are icons which are used to include emotion and other meta-messages otherwise not transmittable in written online communication forms.

[3] Examples include :-) traditional smile ;-) wink, etc. See Sanderson, 1993, for more examples.

[4] The online culture is described and written about in FAQ (frequently asked question) files in various newsgroups, the various news.newuser newsgroups, and in other readily available files (North, 1994).

\section{REFERENCES}

Aizu, Izumi. (1995). Cultural Impact on Network Evolution in Japan Emergence of Netizens [OnLine]. Institute for HyperNetwork Society. GLOCOM (Centre for Global Communications), International University of Japan.

Available WWW: http://www.glocom.ac.jp/Publications/Aizu/nete\&c.html

Avis, Andrew. (1995) Public Spaces on the Information Highway: The Role of Community Networks. Unpublished master's thesis, University of Calgary, Calgary, Alberta, Canada.

Available WWW: http://www.ucalgary.ca/ aavis/thesis/thesis.html

Felsenstein, Lee. (1993, May). The Commons of Information. Dr. Dobbs' Journal 18-22.

Frost, John. (1993). Cyberpoet's Guide to Virtual Culture. Available WWW: http://homepage.seas.upenn.edu/ mengwong/cyber/cgvcl.html

Graham, Garth. (March 29, 1995). A Domain Where Thought is Free to Roam: The Social Purpose of Community Networks. Prepared for Telecommunities Canada for CRTC public hearings on information highway.

Available WWW: http://www.freenet.mb.ca/tc/crtc.brief.html

Hauben, Michael and Ronda Hauben. (1997) Netizens: On The History and Impact of Usenet and the Internet. Los Alamitos, CA: IEEE Computer Society Press.

Also available WWW: http://www.columbia.edu/ hauben/netbook/

Jones, Bruce. (1991) An Ethnography of the Usenet Computer Network: Proposal for a PhD Dissertation in Communications. University of California, San Diego. Dept. of Communication. Available FTP: weber.ucsd.edu Directory: /Usenet.Hist/ File: diss.proposal

Mead, Margaret. (1956). New Lives for Old: Cultural Transformations - Manus, 1928-1953. NY, NY: William Morrow \& Company.

Mead, Margaret. (1978). Culture and Commitment: The New Relationships Between the Generations in 'he 1970s. Garden City, NY: Anchor Books/Doubleday.

North, Tim. (1994) The Internet and Usenet Global Computer Networks: An investigation of their culture and its effects on new users. Unpublished master's thesis, Curtin University of Technology, Perth, Australia.

Available WWW: http://www.vianet.net.au/ timn/thesis/

Sanderson, David W. (Ed.). (1993). Smileys. Sebastopol, CA: O’Reilly \& Associates.

Uncapher, Willard. (1992). Between Local and Global Placing the Media-scape in the Transnational Cultural Flow. Available WWW:

http://www.eff.org/pub/Net_culture/Global_village/between_global_and_local.paper

Weston, Jay. (Nov. 26, 1994). Old Freedoms and New Technologies: The Evolution of Community Networking. [On-Line]. Paper presented at the Free Speech and Privacy In The Information Age Symposium: University of Waterloo, Canada

Available WWW: http://www.nptn.org/cyber.serv/tdp/jweston

Woodbury, Gregory G. (1994, Fall). Net Cultural Assumptions. Net Culture Assumptions II Historical Perspective Amateur Computerist Newsletter, 6

Available FTP: wuarchive.wustl.edu Directory:/doc/misc/acn/ File: acn6-2.txt. 